\title{
A New Semi-Selective Medium for Xanthomonas campestris pv. vitians, the Causal Agent of Bacterial Leaf Spot of Lettuce
}

V. Toussaint, MacDonald Campus of McGill University, 21111 Lakeshore, Ste-Anne-de-Bellevue, Quebec, H9X 3V9, Canada; C. E. Morris, Station de Pathologie Végétale, INRA d'Avignon, 84143, Monfavet, Cedex, France; O. Carisse, Horticultural Research and Development Centre, Agriculture and Agri-Food Canada, 430 Gouin Boulevard, St-Jean-sur-Richelieu, Quebec

\begin{abstract}
Toussaint, V., Morris, C. E., and Carisse, O. 2001. A new semi-selective medium for Xanthomonas campestris pv. vitians, the causal agent of bacterial leaf spot of lettuce. Plant Dis. 85:131-136.

A semi-selective medium containing maltose, methyl green, and antibiotics (MMG) was developed for the isolation of Xanthomonas campestris pv. vitians. The semi-selective medium was evaluated based on plating efficiency of $X$. campestris pv. vitians in cell suspensions of pure cultures from leaves and soil. MMG medium allowed recovery of 5.7 to $30.6 \%$ of the X. campestris pv. vitians colonies recovered on nutrient agar and 0.1 to $8.4 \%$ of those recovered on 1/10-strength tryptic soy agar. MMG inhibited growth of most background bacteria and allowed reliable identification of $X$. campestris pv. vitians. The semi-selective medium contained (per liter) maltose $(10 \mathrm{~g})$, tryptone $(5 \mathrm{~g}), \mathrm{K}_{2} \mathrm{HPO}_{4}(3.5 \mathrm{~g}), \mathrm{KH}_{2} \mathrm{PO}_{4}(2.75 \mathrm{~g})$, trace elements $(0.02$ to $1.0 \mathrm{mg})$, methyl green $(2 \mathrm{ml}$ of a $1 \%$ aqueous solution), amoxicillin $(32 \mathrm{mg})$, cephalothin (32 $\mathrm{mg})$, cycloheximide $(50 \mathrm{mg})$, and agar $(15 \mathrm{~g})$.
\end{abstract}

Bacterial leaf spot of lettuce (BLSL) caused by Xanthomonas campestris pv. vitians is present in several parts of the world and was observed for the first time in Quebec in $1994(2,12,19,22,25)$. BLSL is characterized by water-soaked lesions at the margins of leaves, which become black and necrotic in a few days. As the disease progresses, necrotic lesions can develop on other parts of the leaf. When symptoms are limited to older external leaves, the diseased foliage can be removed at harvest. When symptoms are present on younger leaves, however, plants become unmarketable. This disease is thought to be seedborne, but attempts to reisolate the pathogen from commercial seed lots have failed $(11,24)$. Sahin et al. (15), however, showed that it was possible to produce infected seed from contaminated plants. Management of BLSL with chemical pesticides provides limited control $(3,22)$. Presently,

Corresponding author: V. Toussaint

E-mail: toussaintv@em.agr.ca

V. Toussaint's present address: Horticultural Research and Development Centre, Agriculture and Agri-Food Canada, 430 Gouin Boulevard, St.Jean-sur-Richelieu, Quebec, J3B 3E6, Canada.

This research was supported by Agriculture and Agri-Food Canada and INRA.

Accepted for publication 18 October 2000.

Publication no. D-2000-1204-01R

This article is in the public domain and not copyrightable. It may be freely reprinted with customary crediting of the source. The American Phytopathological Society, 2001. no bactericides are registered in Canada for controlling bacterial diseases on lettuce.

Information on the ecology of $X$. campestris pv. vitians and the epidemiology of BLSL is sparse. $X$. campestris pv. vitians probably survives as an epiphyte, but no reports have been published on the subject. The bacterium has been recovered from lettuce debris buried in soil after an overwintering period but it has never been recovered from soil samples without lettuce debris (27). To carry out epidemiological and ecological studies, a detection method must first be developed. The method should allow the detection, identification and reliable quantification of $X$. campestris pv. vitians populations.

Semi-selective media permit quantification and can be highly sensitive assays. A semi-selective medium was reported to be as sensitive as polymerase chain reaction (PCR) in detecting Xanthomonas albilineans in sugar cane (26). Some semiselective media are even more sensitive than immunological techniques for detecting low numbers of bacteria $(1,26)$. For $X$. campestris pv. vitians, however, none of these methods are available. A semiselective medium is easy to use and less costly than molecular and immunological techniques. Semi-selective media can often be readily used for diverse samples (soil, water, leaf tissue), whereas molecular and immunological techniques may vary in sensitivity according to sample type.

In preliminary experiments, previously described semi-selective media for different pathovars of Xanthomonas were tested but none of them allowed the recovery of
$X$. campestris pv. vitians. Most of the semiselective media developed for Xanthomonas pathovars are based on starch hydrolysis, which leads to clearing of the medium around colonies. The capacity of $X$. campestris pv. vitians to hydrolyze starch is poor (4). Consequently, these media are not suitable for studying this bacterium. Considering that $X$. campestris pv. vitians populations are often low and that this bacterium grows slower than bacterial saprophytes, it is important to develop a semi-selective medium for $X$. campestris pv. vitians. On this new semiselective medium, it should be easy to recognize $X$. campestris pv. vitians but it should also limit the growth of saprophytic bacteria to facilitate enumeration of the pathogen. The objective of this study was to develop a semi-selective medium for the isolation and quantification of $X$. campestris pv. vitians from lettuce plants and soil. The medium was also tested for the isolation of $X$. campestris pv. vitians from commercial lettuce seeds.

\section{MATERIALS AND METHODS}

Bacterial strains. The origins of $X$. campestris pv. vitians strains used in this study are listed in Table 1. The strain LMG938M3 is a rifampicin-resistant mutant selected from the wild type strain, LMG938 grown on one-tenth-strength tryptic soy agar (1/10-TSA) (3 g of tryptic soy broth [211825, Difco, Sparks, Detroit, $\mathrm{MI}]$, and $15 \mathrm{~g}$ of agar per liter) supplemented with $100 \mathrm{mg}$ of rifampicin per liter (R-3501, Sigma, Oakville, Canada). Saprophytic bacteria from field-grown lettuce leaves were obtained by dilution plating of leaf washings on 1/10-TSA supplemented with $50 \mathrm{mg}$ of cycloheximide per liter (C-7698, Sigma). To represent a wide diversity of saprophytic bacteria, strains were chosen according their gram reaction (21) and their color on 1/10TSA. Strains of $X$. campestris pv. vitians were maintained in sterile tap water at room temperature and saprophytes were maintained on 1/10-TSA slants and stored at $4^{\circ} \mathrm{C}$. To evaluate the effect of the different ingredients of the semi-selective medium on saprophytic bacteria, all 20 bacterial saprophytes collected from lettuce leaves were mixed in equal parts. Xanthomonas strains were tested singly and in mixtures. 
Development of the semi-selective medium. The different ingredients of the semi-selective medium were chosen based on their capacity to support the growth of $X$. campestris pv. vitians and to inhibit the saprophytic populations present on lettuce leaves. Each component was tested separately (carbon sources, antibiotics, growth factors, and dyes).

Carbon utilization. The capacity of $X$. campestris pv. vitians' and the saprophytes to use different carbon sources was evaluated on solid minimal medium $(2.7 \mathrm{~g}$ of $\mathrm{KH}_{2} \mathrm{PO}_{4}, 3.5 \mathrm{~g}$ of $\mathrm{K}_{2} \mathrm{HPO}_{4}, 0.2 \mathrm{~g}$ of $\mathrm{MgSO}_{4} \cdot 7 \mathrm{H}_{2} \mathrm{O}, 0.1 \mathrm{~g}$ of $\mathrm{CaCl}_{2}, 15 \mathrm{~g}$ of agar, $1 \mathrm{ml}$ of a trace elements solution [per liter: $9.5 \mathrm{~g}$ of $\mathrm{FeSO}_{4} \cdot 7 \mathrm{H}_{2} \mathrm{O}, 73 \mathrm{mg}$ of $\mathrm{ZnSO}_{4} 7 \mathrm{H}_{2} \mathrm{O}, 68 \mathrm{mg}$ of $\mathrm{CuSO}_{4} \cdot 5 \mathrm{H}_{2} \mathrm{O}, 10$ $\mathrm{mg}$ of $\mathrm{NaMoO}_{4} \cdot 2 \mathrm{H}_{2} \mathrm{O}, 11 \mathrm{mg}$ of $\mathrm{MnSO}_{4} \cdot \mathrm{H}_{2} \mathrm{O}$, and $10 \mathrm{mg}$ of $\mathrm{H}_{3} \mathrm{BO}_{3}$ ], and 1 liter of $\mathrm{ddH}_{2} \mathrm{O}$ ). The carbon sources tested were added to this minimal medium at a final concentration of $1 \%$. Potential carbon sources were chosen based on the results of a BIOLOG assay (23) which screened 96 different carbon sources. The carbon sources selected were glucose, maltose, sucrose, starch, and cellobiose. Each suspension of $X$. campestris pv. vitians and saprophytic bacteria were adjusted approximately to $3 \times 10^{9}$ cells $\left(A_{590}=0.2\right)$. The bacterial suspensions tested were first, a mix of equal parts of each of the 14 strains of $X$. campestris pv. vitians listed in Table 1; second, a mixture of equal parts of each of the 20 strains of saprophytes isolated from lettuce leaves; and third, pure suspensions of the strains LMG938, VT25, VT100, VT106, and VT107. The growth of bacterial strains on the different carbon sources was determined by dilution plating with three replicates per dilution. Colonyforming units (CFU) were counted after an incubation period of $72 \mathrm{~h}$ at $28^{\circ} \mathrm{C}$. Plating efficiency was determined for each carbon source relative to the growth of the strains on the minimal medium containing glucose.

Resistance to antibiotics. Twenty-one strains of $X$. campestris pv. vitians and 24 lettuce leaf saprophytes were tested for their resistance to antibiotics of the commercial antibiograms ATB UR 14030 and ATB ANA 14260 (bioMérieux, Marcy-L'Étoile, France). Inoculation of the antibiograms was done as described by the manufacturer except that bacterial suspensions were adjusted spectrophotometrically to $A_{590}=0.2$. Presence of bacterial growth was noted for each antibiotic and for each strain after 1 and 2 days of incubation at $28^{\circ} \mathrm{C}$.

Table 1. Origin of Xanthomonas campestris pv. vitians strains used in this study

\begin{tabular}{ll}
\hline Strain & Origin \\
\hline 3.10 .3 L3, 3.10.3 L7 & K. Pernezny, Florida \\
BPIC1788 & M. P. G. Psallidas, Greece \\
CFBP3979 & L. Gardan, France \\
LMG938 & LMG Culture Collection \\
VT14, VT25, VT41 & Isolated in Quebec, summer 1996, V. Toussaint \\
VT100, VT106, VT107, VT112, VT115, VT117 & Isolated in Quebec, summer 1998, V. Toussaint \\
\hline
\end{tabular}

To evaluate the efficiency of the semiselective medium in recovering $X$. campestris pv. vitians from 4-week-old plants, greenhouse lettuce plants were sprayed with sterile water, a bacterial suspension of LMG938, or a bacterial suspension of LMG938M3. Both suspensions were adjusted to $A_{590}=0.2$. Inoculated plants were arranged in a greenhouse at $20 \pm 3^{\circ} \mathrm{C}$ according to a randomized complete block design with a total of three blocks and three treatments per block. After incubation (7 days) three plants per block per treatment were collected. Each plant was weighed and then put in a plastic bag to which $20 \mathrm{ml}$ of $0.1 \mathrm{M}$ phosphate buffer at pH $7.0\left(61.5 \mathrm{ml}\right.$ of $\mathrm{K}_{2} \mathrm{HPO}_{4} 1 \mathrm{M}, 38.5 \mathrm{ml}$ of $\mathrm{KH}_{2} \mathrm{PO}_{4} 1 \mathrm{M}$, and $900 \mathrm{ml}$ of $\mathrm{ddH}_{2} \mathrm{O}$ ) was added. Plants were macerated in a stomacher (model 400 laboratory blender, Seward Medical, UK) for $2 \mathrm{~min}$ at high speed. The size of the total bacterial population and of $X$. campestris pv. vitians per gram of lettuce was determined by dilution plating on 1/10-TSA, on the MMG medium, and on 1/10-TSA supplemented with rifampicin at $50 \mathrm{mg}$ per liter. For $X$. campestris pv. vitians-like colonies, 25 were randomly sampled and streaked on yeast chalk agar (29). Their ability to induce a hypersensitive reaction on tobacco and their pathogenicity on lettuce were determined by injecting $0.5 \mathrm{ml}$ of bacterial suspension $\left(A_{590}=0.2\right)$ into plant leaves.

To evaluate the MMG medium's efficiency in recovering $X$. campestris pv. vitians from soil, nine flats were filled with $1.5 \mathrm{~kg}$ of muck soil from the Ste-Clothilde experimental farm of Agriculture and AgriFood Canada, Quebec. Three flats were inoculated with $300 \mathrm{ml}$ of sterile water, three flats with $300 \mathrm{ml}$ of a suspension of LMG938 from a 48-h culture on 1/10TSA, and three with $300 \mathrm{ml}$ of a suspension of LMG938M3 from a 48-h culture on 1/10-TSA. Both bacterial suspensions were adjusted to $A_{590}=0.2$. Flats were arranged in a random complete block design in a greenhouse at $20 \pm 3^{\circ} \mathrm{C}$ and incubated for 4 h. After incubation, three samples of $5 \mathrm{~g}$ of soil were taken from each flat and thoroughly mixed with $20 \mathrm{ml}$ of $0.1 \mathrm{M}$ phosphate buffer $\mathrm{pH}$ 7.0. Bacterial population size was evaluated by dilution plating on the MMG medium, on 1/10-TSA supplemented with $50 \mathrm{mg}$ of rifampicin per liter and on 1/10-TSA.

Statistical analysis. Analyses of variance were conducted on recovery rate $(\%)$ with the general linear model (GLM) procedure (Statistical Analysis System Institute Inc., Cary, NC). Differences among treatment levels were determined using the least significant difference (LSD). The arcsin-square root transformation was not used because some values were greater than $100 \%$.

\section{RESULTS}

Carbon utilization. There was a significant effect of carbon sources on the 
recovery rate of $X$. campestris pv. vitians strains $(P=0.0088)$ and saprophytes $(P=$ $0.0001)$. For $X$. campestris pv. vitians, more bacteria were recovered on starch and sucrose than on glucose, but the variation among strains was large for these two carbon sources. There was no significant difference in the number of bacteria recovered on cellobiose and maltose as compared to the glucose medium (Fig. 1). For saprophytes, CFU recovery on cellobiose, maltose, and starch was significantly greater than on glucose. On sucrose, however, there was an excessive production of slime by the saprophytic bacteria and by $X$. campestris pv. vitians. On maltose, $X$. campestris pv. vitians colonies were circular and convex as opposed to the slimy texture and rapid confluence of the colonies on sucrose. On cellobiose and starch, the colonies developed only after 8 days of incubation and were smaller compared to those on media amended with maltose and glucose. Maltose was selected as the main source of carbon because it prevented the formation of slimy colonies and facilitated the enumeration of bacterial colonies.

Effect of antibiotics. Amoxicillin and cephalothin completely inhibited $33 \%$ of the strains of saprophytes; whereas, each of these antibiotics inhibited only 5\% of the $X$. campestris pv. vitians strains tested. The antibiotics vancomycin, gentamycin, and tobramycin used in different semi-selective media for Xanthomonas (17) inhibited 44, 91 , and $95 \%$, of the $X$. campestris pv. vitians strains, respectively.

Effects of growth factors. There was a significant effect of growth factors on the recovery rate of $X$. campestris pv. vitians ( $P$ $=0.0001)$ and saprophytic bacteria $(P=$ $0.0001)$. For the $X$. campestris pv. vitians, recovery rate was significantly lower on yeast extract than on the medium without growth factors. No significant difference in recovery rate was obtained for methionine, but recovery rate was significantly higher on tryptone compared to the medium without growth factors (Fig. 2). For the saprophytes the recovery rates on tryptone and yeast extract were significantly lower than on the medium without growth factors, yet were significantly higher on methionine (Fig. 2).

Effect of dyes. There was a significant effect of dyes on the recovery rate of $X$. campestris pv. vitians strains $(P=0.0001)$ and saprophytes $(P=0.0004)$. For $X$. campestris pv. vitians, recovery on the medium was significantly reduced by the addition of dyes. The recovery rates were $81.4 \%$ on methyl green and $3.8 \%$ on methyl violet (Fig. 3). For the saprophytes, recovery was also significantly inhibited by the addition of dyes. The presence of methyl green in the medium, however, gave a greenish color to the colonies of $X$. campestris pv. vitians which made them easier to differentiate from other bacteria.

Evaluation of the semi-selective medium. The resulting MMG medium was composed of (per liter): $10 \mathrm{~g}$ of maltose (reference M-5885, Sigma), $5 \mathrm{~g}$ of tryptone (0.123-17-3, Difco), $3.5 \mathrm{~g}$ of $\mathrm{K}_{2} \mathrm{HPO}_{4}$ (P3786, Sigma), $2.75 \mathrm{~g}$ of $\mathrm{KH}_{2} \mathrm{PO}_{4}$ (P-5379, Sigma), $1 \mathrm{ml}$ of trace element (as described above), $2 \mathrm{ml}$ of a $1 \%$ aqueous solution of methyl green (M-8884, Sigma), and $15 \mathrm{~g}$ of agar (0145-07-0, Difco). The $\mathrm{pH}$ was adjusted to 7.0, and the medium was autoclaved $20 \mathrm{~min}$ at $121^{\circ} \mathrm{C}, 15 \mathrm{psi}$. After autoclaving and cooling to about $50^{\circ} \mathrm{C}$, antibiotics were added. Antibiotics were dissolved in ethanol and added at a final concentration of (per liter): $32 \mathrm{mg}$ of amoxicillin (A-8523, Sigma), $32 \mathrm{mg}$ of cephalothin (C-4520, Sigma), and $50 \mathrm{mg}$ of cycloheximide (C-7698, Sigma). On MMG, X. campestris pv. vitians colonies were shiny yellow-green with green centers. Colonies were smooth, circular, and raised $(1$ to $1.5 \mathrm{~mm})$ with an average diameter of $2 \mathrm{~mm}$. After 4 days incubation, a zone of discoloration of the medium was observed around $X$. campestris pv. vitians colonies probably due to the accumulation of the dye by the bacterial colonies. Colonies were easy to identify after 7 days of incubation at $28^{\circ} \mathrm{C}$ (Fig. 4). Other strains of pathovars of Xanthomonas have been

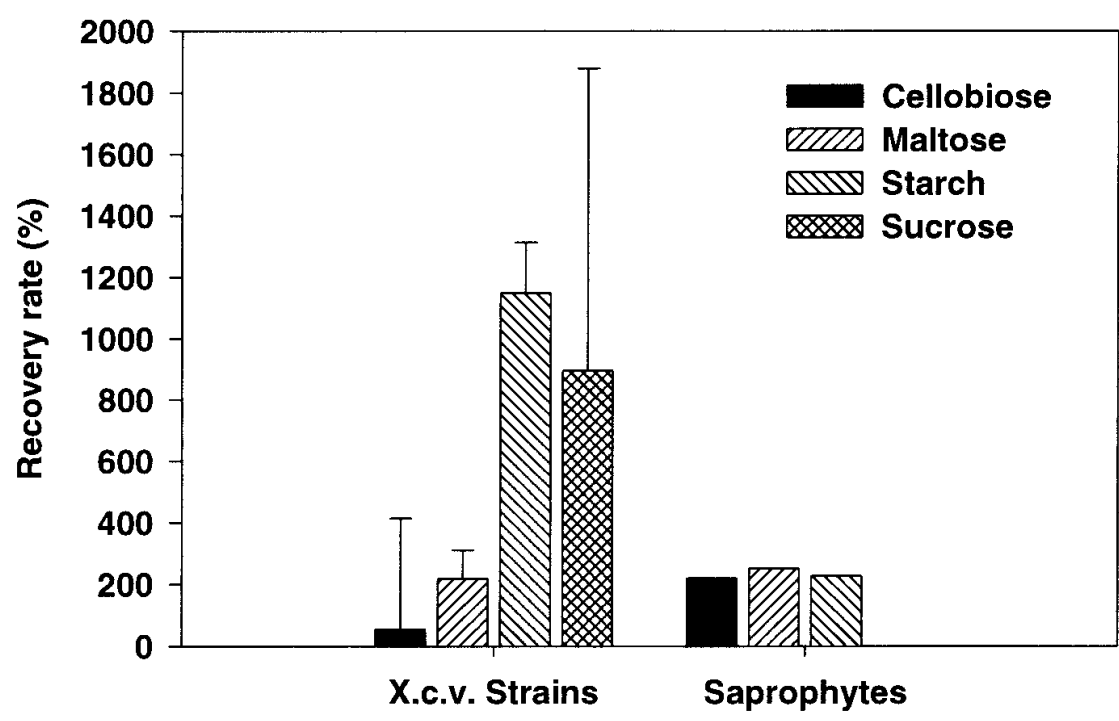

Fig. 1. Recovery rate of Xanthomonas campestris pv. vitians and saprophytes on different carbon sources. For $X$. campestris pv. vitians each bar represents the mean recovery rate (\%) (colony forming units $[\mathrm{CFU}]$ on carbon source medium/CFU on glucose medium $\times 100$ ) for each of six strains of X. campestris pv. vitians (LMG938, VT25, VT100, VT106, and VT107) and a mixture of all 14 of the $X$. campestris pv. vitians strains shown in Table 1 . The standard error of each mean is indicated.

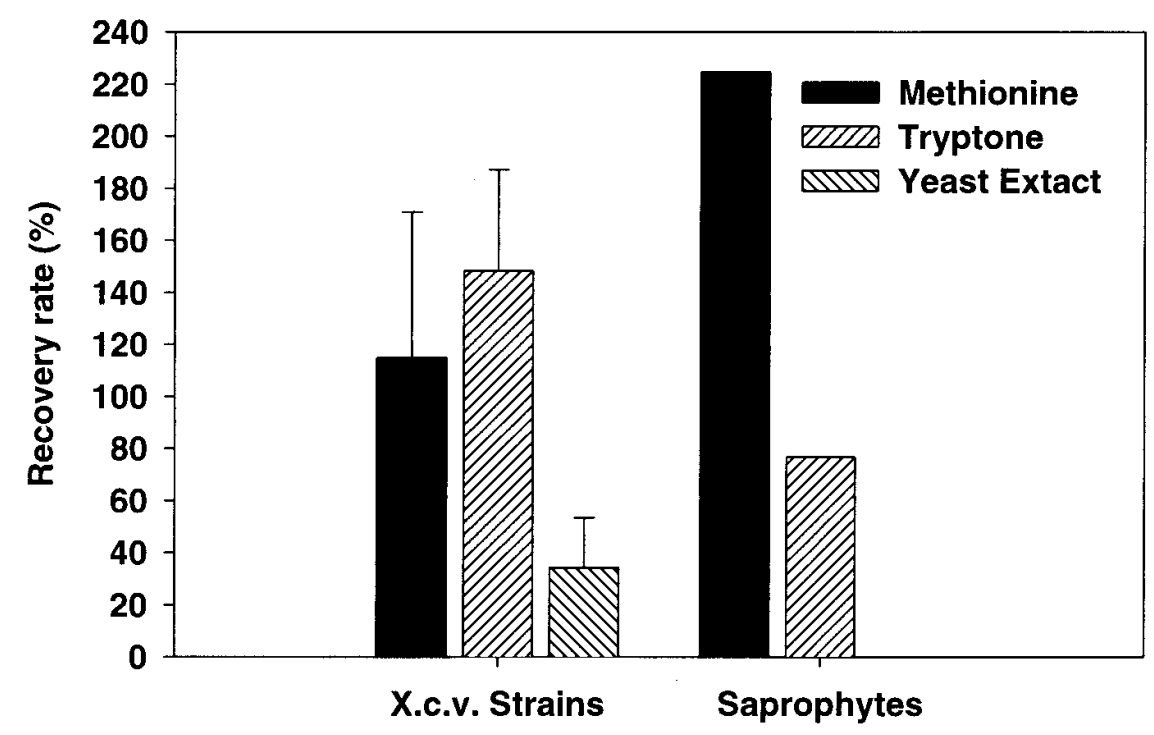

Fig. 2. Recovery rate of Xanthomonas campestris pv. vitians and saprophytes on different growth factors. For $X$. campestris pv. vitians, each bar represents the mean recovery rate (5) (colony forming units [CFU] on growth factors medium/CFU on glucose medium without growth factors $\times 100$ ) for each of six pure strains of $X$. campestris pv. vitians (LMG938, VT25, VT100, VT106, and VT107) and a mixture of all 14 of the $X$. campestris pv. vitians strains presented in Table 1 . The standard error of each mean is indicated. 
grown on the MMG medium, and overall it was possible to differentiate $X$. campestris pv. vitians from others. Tested strains of the pathovars armoraciae, campestris, dieffenbachiae, and juglandis of $X$. campestris, grew faster and had a darker green pigmentation than $X$. campestris pv. vitians on the MMG medium. $X$. campestris pv. vesicatoria grew as fast as $X$. campestris $p v$. vitians, but colonies also showed a darker green pigmentation. Colonies of $X$. campestris pv. syngonii were dark yellow, and $X$. campestris pv. carotae did not grow on the medium at all. Finally, it was difficult to differentiate $X$. campestris pv. alfalfae from $X$. campestris pv. vitians.

The recovery of $X$. campestris pv. vitians on MMG was evaluated in vitro, from lettuce plants, and from soil. For the first in vitro experiment, 2.41 and $4.13 \%$ of the $X$. campestris pv. vitians colonies recovered on 1/10-TSA were recovered on MMG in the first and second trials, respectively (Table 2). X. campestris pv. vitians strains, however, did not grow well on the D-5 medium. MMG medium allowed recovery of 2.0 and $6.6 \%$ of the colonies of saprophytes recovered on $1 / 10$ TSA in the first and second trials, respec-

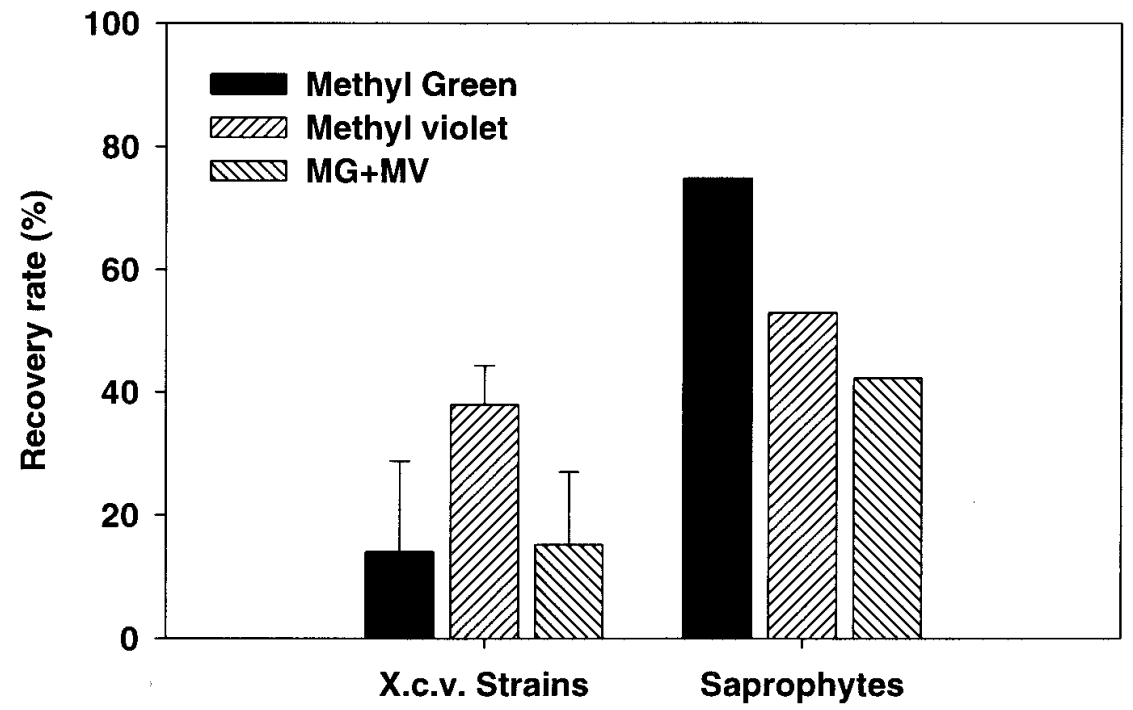

Fig. 3. Recovery rate of Xanthomonas campestris pv. vitians strains and saprophytes on different dyes. For $X$. campestris pv. vitians strains, each bar represents the mean recovery rate (\%) (colony forming units $[\mathrm{CFU}]$ on dyes medium/CFU on glucose medium without dyes $\times 100$ ) for each of six pure strains of $X$. campestris pv. vitians (LMG938, VT25, VT100, VT106, and VT107) and a mixture of all 14 of the $X$. campestris pv. vitians strains presented in Table 1 . The standard error of each mean is indicated.

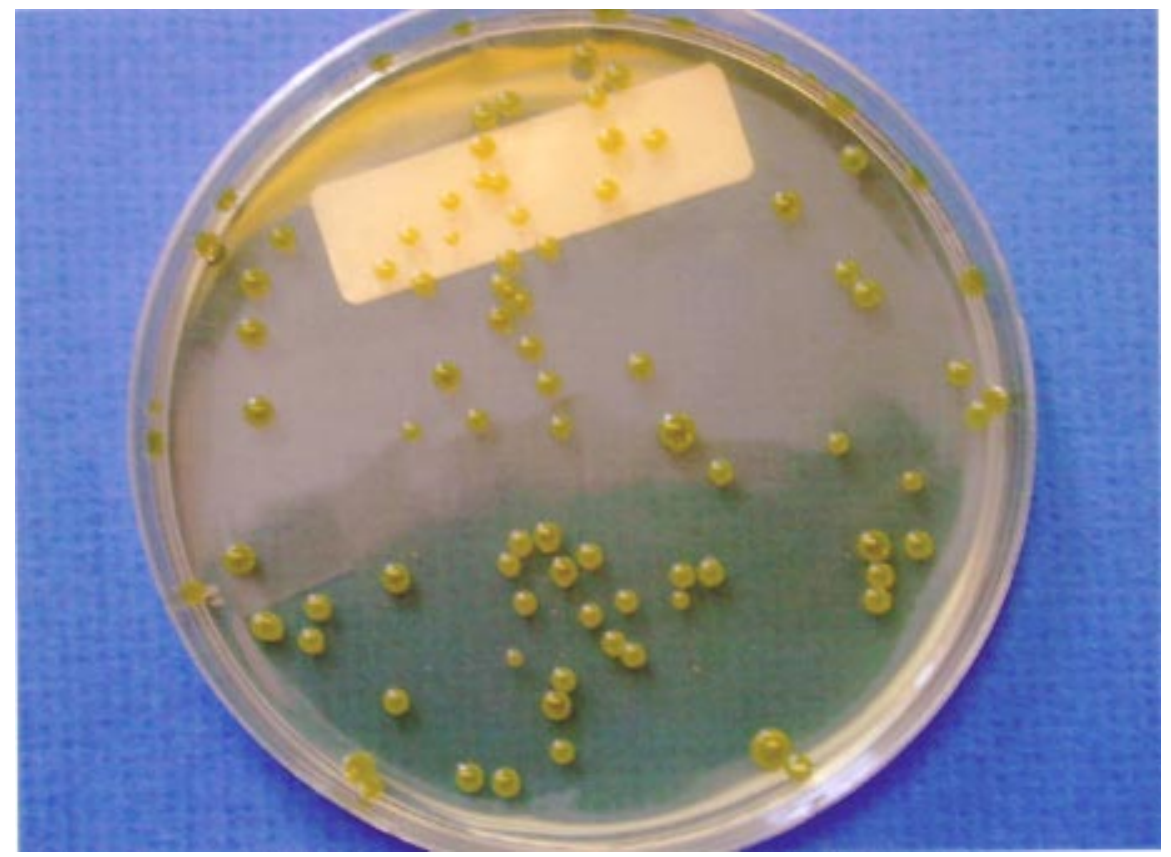

Fig. 4. Xanthomonas campestris pv. vitians colonies on the MMG medium. tively. For the saprophytes on D-5 medium, the recovery rates for the first and second trials were 3.51 and $9.57 \%$, respectively (Table 2). For the second experiment, the recovery rate varied from 5.7 to $149.0 \%$ for the MMG medium compared with that of nutrient agar (Table 3).

On artificially inoculated lettuce leaves, the recovery of strains LMG938 and LMG938M3 was possible from all infected lettuce samples. Colonies of $X$. campestris pv. vitians were countable after 4 days on MMG medium, but were much easier to differentiate from the saprophytes after 7 days of incubation. From the MMG medium, all isolated colonies which were $X$. campestris pv. vitians-like induced an HR in tobacco and were virulent on lettuce. For the plants inoculated with sterile water, 6.6 to $17.4 \%$ of the colonies recovered on 1/10-TSA were recovered on MMG medium, but none of the colonies on MMG medium looked like $X$. campestris pv. vitians colonies. For the plants inoculated with the wild-type strain, LMG938, 5.6 to $10.6 \%$ of the colonies recovered on $1 / 10$ TSA were recovered on MMG medium. For the colonies recovered on MMG medium, 80.0 to $100 \%$ of these colonies were $X$. campestris pv. vitians-like. It was impossible to determine which of the colonies recovered on 1/10-TSA were $X$. campestris pv. vitians. On the plants inoculated with the rifampicin resistant mutant strain LMG938M3, 70.9 to $97.8 \%$ of the colonies recovered on 1/10-TSA were recovered on the MMG medium and 82.8 to $100 \%$ of the colonies recovered on 1/10-TSA were recovered on 1/10-TSA supplemented with rifampicin. All the colonies recovered on MMG and 1/10-TSA supplemented with rifampicin were $X$. campestris pv. vitianslike.

For the soil experiment, the rifampicinresistant strain LMG938M3 was inoculated at a final concentration of $9.3 \times 10^{7} \mathrm{CFU}$ $\mathrm{g}^{-1}$ of soil. The recovery was $6.7 \times 10^{6}$ $\mathrm{CFU} \mathrm{g}{ }^{-1}$ of soil on MMG medium and 8.7 $\times 10^{6} \mathrm{CFU} \mathrm{\textrm {g } ^ { - 1 }}$ of soil on 1/10-TSArifampicin medium after an incubation period of $4 \mathrm{~h}$. For the wild type strain LMG938, the bacteria were inoculated at a final concentration of $7.2 \times 10^{7} \mathrm{CFU} \mathrm{g}^{-1}$ of soil and $5.9 \times 10^{5} \mathrm{CFU} \mathrm{g}^{-1}$ were recovered after $4 \mathrm{~h}$ of incubation.

\section{DISCUSSION}

MMG medium allowed the recovery of $X$. campestris pv. vitians from bacterial suspensions, lettuce leaves and soil samples. As expected, the recovery rate was much lower on MMG medium than on a non-selective medium such as 1/10-TSA. But on a non-selective medium it is nearly impossible to identify colonies of $X$. campestris pv. vitians and to quantify bacterial populations. On MMG quantification was possible because most of the saprophytes were inhibited and because of the differential color and shape of the colonies of $X$. 
campestris pv. vitians. TSA has been reported to be an excellent medium for the recovery of Escherichia coli from a wide range of environments $(9,14,20)$, but also for miscellaneous bacteria. The recovery rate on the MMG medium is higher when compared to nutrient agar. The recovery rate of $X$. campestris pv. vitians on TZC is high, but saprophytes grow easily on this non-selective medium. For the SM medium, the recovery rate is lower than on MMG (4). On SM, the colonies are very small and no hydrolysis zone is observed around $X$. campestris pv. vitians colonies.

Other media for Xanthomonas spp. such as SX (16) or FS (30) did not allow the recovery of $X$. campestris pv. vitians from soil and plant tissues probably because $X$. campestris pv. vitians is inhibited by the methyl violet present in these media. In addition, there was no recovery of $X$. campestris pv. vitians strains from bacterial suspensions, lettuce leaves, or soil on D-5 medium. It has already been reported that D-5 is a poor medium for isolation of Xanthomonas pathovars $(4,17)$. Moreover, antibiotics such as gentamycin, tobramycin, and vancomycin present in this and other semi-selective media for Xanthomonas spp. $(5,8,10,13,18,28)$ inhibit the growth of $X$. campestris pv. vitians strains. This could explain, at least in part, why these media were not useful for the isolation of $X$. campestris pv. vitians. $X$. campestris pv. vitians is a slow grower compared to most saprophytes, hence, a compromise must be made between the selectivity of the medium and the desired recovery rate.

To avoid the degradation of antibiotics and dyes, the MMG medium must be stored under cold, dark conditions. When it is stored at room temperature in the presence of light, the color of the medium changes and colonies of $X$. campestris pv. vitians are less typical and become harder to identify. The MMG medium is easy to prepare. Stock trace minerals and dye solutions can be prepared in advance and stored at $4^{\circ} \mathrm{C}$ in dark conditions. The colonies of $X$. campestris pv. vitians are easily recognizable because of their color and their shape on the MMG medium. As for any semi-selective medium, reference strain should always be included in the test to ensure proper identification of the bacteria of interest. Moreover, no UV light or reactive is required for counting colonies, which makes this medium easy to use. Finally, MMG medium will also be a useful tool for diagnosing BLSL, and for recovering bacteria from lettuce plants, infested soil, or other sources of inoculum.

\section{LITERATURE CITED}

1. Alvarez, A. M., and Lou, K. 1985. Rapid identification of Xanthomonas campestris pv. campestris by ELISA. Plant Dis. 69:10821086.

2. Burkholder, W. H. 1954. Three bacteria pathogenic on head lettuce in New York State. Phytopathology 44:592-596.

3. Carisse, O., Ouimet, A., Toussaint, V., and Philion, V. 2000. Evaluation of the effect of seed treatments, bactericides, and cultivars on bacterial leaf spot of lettuce caused by Xanthomonas campestris pv. vitians. Plant Dis. 84:295-299.

4. Chun, W. W., and Alvarez, A. M. 1983. A starch-methionine medium for isolation of Xanthomonas campestris pv. campestris from plant debris in soil. Plant Dis. 67:632-635.

5. Claflin, L. E., Vidaver, A. K., and Sasser, M. 1987. MXP, a semi-selective medium for Xanthomonas campestris pv. phaseoli. Phytopathology 77:730-734.

Table 2. Plate counts and plating efficiency for Xanthomonas campestris pv. vitians and saprophytes in the first in vitro experiment

\begin{tabular}{|c|c|c|c|c|c|c|}
\hline \multirow[b]{2}{*}{ Strain } & \multirow[b]{2}{*}{ Trials } & \multicolumn{3}{|c|}{ Colonies per plate ${ }^{\mathrm{a}}$} & \multicolumn{2}{|c|}{ Plating efficiency ${ }^{\mathrm{b}}$} \\
\hline & & 1/10-TSA & D-5 & MMG & D-5 & MMG \\
\hline \multirow[t]{2}{*}{ Mixture of $X$. campestris pv. vitians } & 1 & $2,710.3$ & 0.0 & 65.3 & 0.0 & 2.4 \\
\hline & 2 & $4,376.7$ & 0.0 & 180.7 & 0.0 & 4.1 \\
\hline \multirow[t]{2}{*}{ Mixture of saprophytes } & 1 & 703.3 & 24.7 & 14.0 & 3.51 & 2.0 \\
\hline & 2 & 850.0 & 81.3 & 55.7 & 9.57 & 6.65 \\
\hline
\end{tabular}

a Plates counts adjusted to the same dilution. $1 / 10-\mathrm{TSA}=$ one-tenth-strength tryptic soy agar; D- $5=$ medium from Kado and Heskett (6); MMG = maltose methyl green medium (semi-selective medium for $X$. campestris pv. vitians).

${ }^{\mathrm{b}}$ Plating efficiency $=($ mean $\#$ of CFU on semi selective medium/mean \# of CFU on $1 / 10-\mathrm{TSA}) \times$ 100 .
6. Kado, C. I., and Heskett, M. G. 1970. Selective media for isolation of Agrobacterium, Corynebacterium, Erwinia, Pseudomonas, and Xanthomonas. Phytopathology 60:969976.

7. Kelman, A. 1954. The reltionship of pathogenicity in Pseudomonas solanacearum to colony appearance on tetrazolium medium. Phytopathology 44:693-695.

8. Kim, H. K. 1982. Epidemiological, genetical, and physiological studies of the bacterial leaf streak pathogen, Xanthomonas campestris pv. translucens (J. J. R.) Dowson. Ph.D. diss. Montana State Univ., Bozeman.

9. McCleery, D. R., and Rowe, M. T. 1995. Development of a selective plating technique for the recovery of Escherichia coli $\mathrm{O} 157: \mathrm{H} 7$ after heat stress. Lett. Appl. Microbiol. 21:252-256.

10. McGuire, R. G., Jones, J. B., and Sasser, M. 1986. Tween media for semiselective isolation of Xanthomonas campestris pv. vesicatoria from soil and plant material. Plant Dis. 70:887-891.

11. Ohata, K., Serizawa, S., Azegami, K., and Shirata, A. 1982. Possibility of seed transmission of Xanthomonas campestris pv. vitians, the pathogen of bacterial spot of lettuce. Bull. Nat. Ins. Agric. Sci. 36:81-88.

12. Pernezny, K., Raid, R. N., Stall, R. E., Hodge, N. C., and Collins, J. 1995. An outbreak of bacterial spot of lettuce in Florida caused by Xanthomonas campestris pv. vitians. Plant Dis. 79:359-360.

13. Randhawa, P., and Schaad, N. W. 1984. Selective isolation of Xanthomonas campestris pv. juglandis from walnut buds and catkins. Phytopathology 74:268-272.

14. Rocelle, M., Clavero, S., and Beuchat, L. R. 1995. Suitability of selective plating media for recovering heat- or freeze-stressed $E s$ cherichia coli $\mathrm{O} 157: \mathrm{H7}$ from trypic soy broth and ground beef. Appl. Environ. Microbiol. 61:3268-3273.

15. Sahin, F., and Miller, S. A. 1997. Identification of the bacterial leaf spot pathogen of lettuce, Xanthomonas campestris pv. vitians, in Ohio, and assessment of cultivar resistance and seed treatment. Plant Dis. 81:1443-1446.

16. Schaad, N. W. 1972. A new medium for the isolation of Xanthomonas campestris. (Abstr.) Phytopathology 62:787.

17. Schaad, N. W. 1988. Laboratory Guide for Identification of Plant Pathogenic Bacteria. American Phytopathological Society, St. Paul.

18. Schaad, N. W., and White, W. C. 1985. A selective medium for soil isolating Xanthomonas campestris pv. translucens from wheat seeds. Phytopathology 75:260-263.

19. Schroth, M. N., Thompson, J. P., Bardin, R., and Greathead, A. 1964. A new disease in California: Bacterial spot of lettuce. Calif. Agric. 18:2-3.

20. Silk, T. M., and Donnelly, C. W. 1997. Increased detection of acid-injured Escherichia coli $\mathrm{O} 157: \mathrm{H} 7$ in autoclaved apple cider by using nonselective repair on trypticase soy agar. J. Food Protec. 60:1483.

Table 3. Plate counts and plating efficiency for Xanthomonas campestris pv. vitians and saprophytes in the second in vitro experiment

\begin{tabular}{|c|c|c|c|c|c|c|c|c|c|}
\hline \multirow[b]{2}{*}{ Strain } & \multicolumn{5}{|c|}{ Colonies per plate ${ }^{\mathrm{a}}$} & \multicolumn{4}{|c|}{ Plating efficiency $^{\mathrm{b}}$} \\
\hline & NA & 1/10-TSA & MMG & SM & TZC & 1/10-TSA & MMG & SM & TZC \\
\hline Mixture of $X$. campestris pv. vitians & 45 & 73 & 13 & 4 & 45 & 162.2 & 28.8 & 8.9 & 100 \\
\hline LMG938 & 77 & 1,185 & 170 & 295 & 11 & $1,539.0$ & 220.8 & 383.1 & 14.2 \\
\hline VT25 & 989 & 4,810 & 56 & 59 & 872 & 486.3 & 5.7 & 5.9 & 88.2 \\
\hline VT41 & 320 & 1,162 & 98 & 40 & 150 & 363.1 & 30.6 & 12.5 & 46.9 \\
\hline Mixture of saprophytes & 142 & 320 & 10 & 33 & 55 & 225.3 & 23.8 & 23.2 & 38.7 \\
\hline
\end{tabular}

a Plates counts adjusted to the same dilution. NA = nutrient agar, 1/10-TSA = one-tenth-strength tryptic soy agar, MMG = maltose methyl green medium (semi-selective medium for $X$. campestris pv. vitians), $\mathrm{SM}=$ starch-methionine medium (4), and TZC = tetrazolium chloride medium (7).

${ }^{\mathrm{b}}$ Plating efficiency $=($ mean \# of CFU on semi selective medium/mean \# of CFU on 1/10-TSA $) \times 100$. 
21. Suslow, T. V., Shroth, M. N., and Isaka, M. 1982. Application of a rapid method for Gram differentiation of plant pathogenic and saprophytic bacteria without staining. Phytopathology 72:917-918.

22. Toussaint, V. 1999. Bacterial leaf spot, a new disease of lettuce in Quebec caused by Xanthomonas campestris pv. vitians. Phytoprotection 80:121-125.

23. Toussaint, V., Morris, C. E., and Carisse, O. 1998. Identification, resistance to antibiotics, and utilization of carbon sources by Xanthomonas campestris pv. vitians strains isolated from different lettuce growing areas. Abstract 3.3.36 in: Abstracts of invited and offered papers, 7th Int. Congr. Plant Pathol., Edinburgh,
Scotland.

24. Umesh, K. C., Koike, S. T., and Gilbertson, R. L. 1996. Association of Xanthomonas campestris pv. vitians with lettuce seed. (Abstr.) Phytopathology 86:S3.

25. Wallis, F. M., and Joubert, J. J. 1972. Bacterial leaf spot of lettuce in Natal. Phytolactica 4:137-138.

26. Wang, Z. K., Comstock, J. C., Hatzoloukas, E., and Schaad, N. W. 1999. Comparison of PCR, BIO-PCR, DIA, ELISA, and isolation on semiselective medium for detection of Xanthomonas albilineans, the causal agent of leaf scald of sugarcane. Plant Pathol. 48:245-252.

27. Wellman-Desbiens, E. 1998. Études sur les sources de contamination par les bactéries responsables de la nervation noire du chou et de la nécrose marginale de la laitue. M.Sc. Diss. Sherbrooke University, Sherbrooke.

28. Williford, R. E., and Schaad, N. W. 1984. Agar medium for selective isolation of Xanthomonas campestris pv. carotae from carrot seeds. (Abstr.) Phytopathology 74:1142.

29. Wilson, E. E., Fakhery, M. Z., and Fredrickson, D. L. 1967. Bacterial phloem canker, new disease of Persian walnut trees. Phytopathology 57:618-621.

30. Yuen, G. Y., Alvarez, A. M., Benedict, A. A. and Trotter, K. J. 1987. Use of monoclonal antibodies to monitor the dissemination of Xanthomonas campestris pv. campestris. Phytopathology 77:366-370. 